\title{
Sustaining Human Rights and Responsibility: The United Nations Global Compact and Myanmar
}

\author{
By Kenneth Christie * \\ Robert James Hanlon ${ }^{+}$
}

Human Rights and Corporate Social Responsibility are not two concepts/perspectives that come to mind when dealing with Myanmar. Beginning in 2012 however, the country has made some determined efforts to promote liberal economic and political reforms in an effort to modernise and open itself to the world. In May 2012, UN Secretary General Ban Ki-moon successfully launched the United Nations Global Compact (UNGC) in Myanmar. The initiative was endorsed by fifteen prominent Burmese business leaders who voiced their commitment to uphold the core principles of the Compact. This paper argues that despite its weakness, the UNGC has the potential to be an effective initiative for promoting ethical business in Myanmar. Drawing on constructivist theory, this paper frames the Compact as a transformative mechanism that incorporates the language of human rights and ethics into corporate and local business practices. Preliminary findings suggest that the UNGC's launch in Burma is opening new space for ethical investors and the promotion of human rights standards in corporate and political governance.

\section{Introduction}

Human rights and corporate social responsibility are not two concepts/ perspectives that come to mind when dealing with Myanmar ${ }^{1}$, a pariah state that has been isolated from mainstream development in Southeast Asia for decades. Beginning in 2011 however, the government made some determined efforts to promote liberal economic and political reforms in an effort to modernise and open itself to the region and the world. Myanmar still remains fragile though and is ranked 21st most dysfunctional state on the Failed State Index (Foreign Policy, 2013). The country suffers from endemic corruption,

\footnotetext{
*Professor, School of Humanitarian Studies, Royal Roads University, Canada.

${ }^{+}$Professor, Institute of Asian Research, University of British Columbia, Canada.ל

${ }^{1}$ In the 1989, the military regime changed the name from Burma to the 'Union of Myanmar'. Today, the country's official name is Republic of the Union of Myanmar. For the purpose of this paper, we refer to both Myanmar and Burma interchangeably. For an good overview of the name debate see: Ian Holliday, (2011), Burma Redux: Global Justice and the Quest for Political Reform in Myanmar, New York: Columbia.
} 
systematic human rights violations, weak rule of law and infrastructure, combined with a negative business climate (Bissinger 2012). Despite such a bleak investment environment, the Asian Development Bank (ADB) expects Myanmar to experience some of the region's fastest growth rate in the coming decade (ADB 2012). Activists and analysts alike have now expressed concern for such growth as bringing adverse social and environmental consequences. The easing of sanctions coupled with the so-called 'scramble for Burma' atmosphere prompted Human Rights Watch to comment that new investments moving into Myanmar may contribute to rights abuses and undermine any reform (Human Rights Watch, 2012). One of the more significant responses to such fears has been the introduction of the United Nations Global Compact (UNGC) in Myanmar.

In May 2012, UN Secretary General Ban Ki-moon successfully launched a local chapter of the UNGC in Myanmar. The initiative was endorsed by fifteen prominent Burmese business leaders who voiced their commitment to uphold the core principles of the Compact. The UNGCs appeal within the Myanmar context is important considering its established reputation as an influential voluntary governance regime. With over 8700 signatories worldwide, the UNGC is a popular initiative for business actors seeking to promote corporate social responsibility; however, the scheme is frequently criticised for elitism and its inability to monitor and enforce the principles upon its members. It has been referred to as a 'toothless' mechanism and little more than a sophisticated public relations platform for industry. Still, Ban Ki-moon called the launch a 'milestone' for Myanmar's commitment to CSR (United Nations, 2012).

We ask the question here of whether the UNGC has the potential to be an effective initiative for promoting ethical business and human rights in Myanmar. To address this question, we have divided this article in four sections. First, we provide a general overview of Myanmar's development process within a human rights context. Second, we draw on constructivist theory and frame the Compact as a transformative mechanism that incorporates the language of human rights and ethics into corporate and local business practices. Third, we conceptualize the role of the UNGC in Myanmar as of voluntary governance organization. Finally, the paper offers a set of policy recommendations of how foreign investors can implement the UNGC into their business models in Myanmar. The paper concludes that although a local UNGC network has emerged in Myanmar, human rights will likely remain a low priority for business in the foreseeable future. On the other hand, constructivism allows us to propose that the UNGC in Burma is opening new space for ethical investors. In this sense, the UNGCs long term impact could bring significant human rights gains by shaping the discourse around business and rights in Burma.

\section{Development in Myanmar}

Myanmar is one of Asia's poorest countries with a per capita GDP ranging between \$800-\$1000/annum (World Bank 2013). The average Burmese citizen 
struggles to establish basic levels of human security with nearly a fifth of population living in extreme poverty on less than \$US 1.25 /day while 75 percent of the population has no access to electricity (World Bank 2013; UNDP 2012; Holliday 2011a). In 2012, Myanmar ranked 149 out of 186 states on the UN's Human Development Index and was classified the fifth most corrupt country in the world by Transparency International (UN-MDG 2012; TI 2012). The country's lack of development coupled with political instability and protracted ethnic conflicts have created a fragile state of insecurity (Howe and Jang 2013).

These development struggles are not new in this context; rather, they are entrenched and been present since the country's inception. Nearly five decades of military rule under General Ne Win along with the establishment of a quasisocialist economy until the late 1980s posed major challenges (David and Holliday 2012). Myanmar's democratic transition only began in 2010 with elections which led to the installation of a hybrid-civilian government a year later.

The regime however continues continue to conduct low-level violations such as illegal searches of property and use of arbitrary threats against the public by law enforcement to acquire information. Myanmar's judiciary has not undergone reform since the day of military rule and questions surrounding its independence and transparency remain. The Asian Human Rights Commission (2012) has reported that the executive continues to give direction on what cases should be considered by the court suggesting "legal professionals agree that the judiciary remains compliant and beholden to administrative demands" (p.2). Corruption is endemic and "pervades all aspects of the work of the justice system" (AHRC 2012, p. 3).

Historically, Myanmar's human rights situation has been anything but abysmal. Human Rights Watch (2009) has frequently cited examples of arbitrary arrests, political prisoners and child soldiers. They accused the military of attacking civilians and fuelling ethnic conflict in the north of the country. In 2010, Amnesty International also accused the junta of similar violations.

Myanmar's rights record had also led many governments in the West to apply sanctions against the regime. As sanctions have eased since Myanmar's democratization process, there is a vibrant debate on whether the country's former rulers can be held accountable for their past offences. David and Holliday (2012) have considered the implications of introducing an international tribunal to explore past crimes. However, they suggest that such a commission could undermine the purpose of sanctions in the first place (David and Holliday 2012, p. 122). Their study also argues that a significant grouping of prominent Burma scholars consider the lifting of sanctions as only having a marginal utility within the context of international justice. Still, the dramatic changes in the country's governance model have opened new space for human rights. 


\section{Foreign Business Actors in Myanmar}

The main investors in Burma are China, Hong Kong, South Korea and Thailand (Bissinger 2012). Western investment is still noticeably absent but this is set to change. On what has been referred to as a type of 'gold rush', hundreds of Western multinational enterprises are considering how they may best enter Asia's newest emerging economy (Forbes 2013; Guardian 2012). Western energy firms are among the most eager to enter the market. The government has announced exploration licenses for foreign firms so long as they enter a joint-venture partnership with a Burmese company. The country's new foreign investment law (FIL) has also proved valuable with foreign direct investment (FDI) in the manufacturing sector is on pace to double in 2013 from the previous year while FDI in the tourism and telecom sectors is set to surge (Myanmar Times 2013).

Still, Bissinger (2012) notes that most FDI that has entered the economy has not translated directly into significant employment growth even with large scale investments from in the extractive sector. Extractives account for 68 percent of total foreign investment with China serving as the country's top investor (Bissinger 2012). Still, Myanmar faces immense development challenges especially in the areas of labour and the environment. Sovacool (2012) notes that resource industries such as logging, fishing and prospecting will be increasing on the rise with calls for sustainable development becoming ever more critical. The private sector's endorsement of the UNGC signals a shift in thinking on what type of investment Burmese people consider appropriate. The government has even called on a national minimum wage to ensure Burmese citizens perceive the reform period in a positive light (Kulczuga 2013). Politically endorsed sustainable development and corporate social responsibility not only places the onus of responsible development on the investor, it signals to the electorate that the government is serious towards the wellbeing of the community. Furthermore, it sends a clear message to Myanmar's current investors that it expects certain levels of social responsibility. Pledging support for the UNGC can essentially act as a barrier to companies that do not incorporate its principles into its business model.

We argue that the launch of the UNGC in Myanmar is little more than a signal to the international community that local entrepreneurs are looking to diversify their investment portfolio. CSR is slowly emerging as a key theme of doing business in Myanmar's reform period. Myanmar's contentious relationship with China is driving the private sector to endorse voluntary global governance mechanisms such as the UN Global Compact.

\section{Constructivism and the UNGC as a Global Governance Regime}

This paper analyses the case of Myanmar through the lens of social constructivism. This theory which has been used in international relations theory really represents a broad approach in that it tries to find an answer to the 
difficulties in traditional IR theory (specifically post modern critiques of that theory) so that we can move forward in empirical, policy oriented research. Thus the relationship between structure and agency are central to the theory. In this sense we will look at the role of norms, ideas and institutions as central to our explanation of Myanmar's relationship with the UN. We are eschewing the extremes ends of IR theory by looking at an interdisciplinary middle ground with the reality that constructivism is a social theory which is useful in investigating these relationships. Social features then are not accepted as a given but rather "constructed" by the context in which people and their actions find themselves.

The United Nations Global Compact (UNGC) is a construct founded on the idea of business-society relationship that injects political, economic and institutional discourse into the consciousness of business (Kell 2012, p. 34). It can be described as a global policy network that endorses a set of ten principles that center around human rights, labour standards, the environment and anticorruption (See Table 1). According to Blowfield and Murray (2008), the UNGC can be understood as a set of voluntary guidelines as opposed to a regulated code of conduct. Second, the Compact does not replace governmental regulation. Third, the UNGC endorses a shared set of universal claims of justice and rights. Finally, the Compact is considered a partnership between various stakeholders looking to develop greater awareness around issues of social responsibility. Based on Blowfield and Murray's description, the UNG can be considered voluntary global governance regime.

Table 1._United Nations Global Compact: 10 Principles

\begin{tabular}{|l|l|}
\hline Principle 1 & $\begin{array}{l}\text { Businesses should support and respect the protection of internationally } \\
\text { proclaimed human rights; and }\end{array}$ \\
\hline Principle 2 & make sure that they are not complicit in human rights abuses. \\
\hline Principle 3 & $\begin{array}{l}\text { Businesses should uphold the freedom of association and the effective } \\
\text { recognition of the right to collective bargaining; }\end{array}$ \\
\hline Principle 4 & the elimination of all forms of forced and compulsory labour; \\
\hline Principle 5 & the effective abolition of child labour; and \\
\hline Principle 6 & $\begin{array}{l}\text { the elimination of discrimination in respect of employment and } \\
\text { occupation. }\end{array}$ \\
\hline Principle 7 & $\begin{array}{l}\text { Businesses should support a precautionary approach to environmental } \\
\text { challenges; }\end{array}$ \\
\hline Principle 8 & $\begin{array}{l}\text { undertake initiatives to promote greater environmental responsibility; } \\
\text { and }\end{array}$ \\
\hline Principle 9 & $\begin{array}{l}\text { encourage the development and diffusion of environmentally friendly } \\
\text { technologies. }\end{array}$ \\
\hline Principle 10 & $\begin{array}{l}\text { Businesses should work against corruption in all its forms, including } \\
\text { extortion and bribery. }\end{array}$ \\
\hline Source: UNGC 2013
\end{tabular}

The UNGC can be considered a voluntary private global governance mechanism that seeks to mobilize a vast global policy network. The compact is not meant to solve the challenges of capitalism or any other economic system 
for that matter; instead it is meant to raise awareness social awareness within the business community especially to concerning values endorsed by the UN (Kell and Levin 2003). As the UNGCs executive director Georg Kell (2012) notes, the United Nations (UN) recognition of multinational corporations (MNC) as significant actors within the sphere of international relations signals a fundamental shift in thinking at the UN. No longer is the intergovernmental organization reserved for nation-states; rather, the institution now regularly consults non-state actors such as MNCs and non-governmental organizations on issues ranging from economic trade to global conflict. This change has been primarily brought on by globalization and has pressured the intergovernmental body to consider how non-state actors influence the international landscape.

Kofi Annan recognized this transformation early on and introduced the idea of a Global Compact in a keynote address at the World Economic Forum. Annan's vision aimed to improve trust between the UN and business community while aligning UN issues with the emerging corporate social responsibility (CSR) movement (Rasche and Kell, 2010). Annan challenged the business community noting

Many of you are big investors, employers and producers in dozens of different countries across the world. That power brings with it great opportunities - and great responsibilities. You can uphold human rights and decent labour and environmental standards directly, by your own conduct of your own business. Indeed, you can use these universal values as the cement binding together your global corporations, since they are values people all over the world will recognise as their own. You can make sure that in your own corporate practices you uphold and respect human rights; and that you are not yourselves complicit in human rights abuses.

(UNEP n.d., p. 15).

Kell (2012) notes that Annan's was essentially attempting to communicate the UN's mandate in the hopes of shoring up support from the American business community. Annan`s speech was risky since it raised the issue of how the IGO would tackle globalization. It also highlighted the need for nonfinancial issues such as human rights and the environment to be considered a part of the business agenda. Moreover, it was introduced without the consultation of its member states. Initially, countries from the Global South were skeptical and feared the UNGC would create trade barriers.

Today, virtually all governments see the UNGC as a tool to mobilizing the private sector. In OECD states, the UNGC is seen as a positive mechanism for addressing the backlash of trade liberalization. It represents the emerging trend towards institutionalized CSR (Vogel, 2008, 2010; Waddock, 2008). Governments now take a proactive lead in developing and promoting the UNGC. Business participants have grown roughly 50 percent since its inception. As of October 2012, the UNGC had 7,000 businesses based in 145 
countries, while by January 2011 roughly 2,048 companies had been expelled for non-compliance (Kell, 2012).

CSR not only focuses on the profit maximizing; rather it incorporates social and environmental themes into the discourse of business. The Corporate Social Responsibility Initiative at Harvard defines CSR as "Corporate social responsibility encompasses not only what companies do with their profits, but also how they make them. It goes beyond philanthropy and compliance and addresses how companies manage their economic, social, and environmental impacts, as well as their relationships in all key spheres of influence: the workplace, the marketplace, the supply chain, the community, and the public policy realm" (CSRI Online 2013).

\section{The UNGC and Myanmar}

This paper argues that the power of ideas will influence industry and political elites in Myanmar to consider CSR as an important business strategy. Using constructivist theory, we propose that basic arguments for endorsements of social responsibility will spread within the business community. If further suggests that by positioning the domestic private sector as a responsible investment community, Myanmar will be able to leverage itself as a progressive and stable FDI destination. Moreover, we posit that although the UN Global Compact is a voluntary and relatively new initiative in Burma, it has significant potential for shaping the direction of Myanmar's business discourse. Despite the impact of the UNGC being minimal in the initial stages, constructivist theory allows us to view the long term influence of the Compact as a meaningful mechanism for building trust amongst diverse stakeholders. This trust will be a critical step in developing an investment climate around social responsibility.

As Gilbert and Behman (2012) have argued, the theme of 'trust' is central to the UNGC. Supporting the UNGC can lead to the advocacy of business ethics, the promotion of codes of conduct, knowledge sharing and CSR capacity building (Witte and Reinicke 2005, p. X). It also allows participants to promote free markets through an ethical framework that does not simply view profit as the only function of business. When Kofi Annan laid out his vision for the UNGC, Waddock (2013) noted that “Annan's speech made an immediate impact on the executives in attendance in part because they were already attuned to the criticisms of globalization that their companies faced and were open to doing something constructive about those criticisms" (p. 52). The Compact moved beyond an ideology of maximizing profits and provided perspective on the social and environmental impact of business (Smurthwaite 2008). The question we raise in this research is whether the UNGC can serve as a mechanism for justice in Myanmar within the context of corporate social responsibility.

As Rashe et al. (2012) notes, there has been little written on UNGC networks in Asia. We selected Myanmar as our case study for several reasons. 
First, there has been a sharp rise in foreign business activity in the country since social and economic reforms. We are interested in understanding how this investment is impacting the country. A second reason is that it is widely considered one of Southeast Asia's last investment destinations; Myanmar is playing catch-up with the region. Again, we are concerned with how development will proceed especially in the context of the government's recent reforms. Still, China is transforming itself and is contacting Burmese companies and communicating that they are changing their old policies of aligning with the regime.

\section{Conclusion}

Myanmar has emerged from decades of developmental isolation into a new context in a world region that has defined for many the economic concepts of globalization. In the 1990's East Asia and Southeast Asia were at the forefront of an economic miracle according to the World Bank. By the end of that decade this miracle had dissipated and collapsed leaving insecurity and hardship as the region realised it was subject to the vagaries of capitalism like anywhere else. In many ways Myanmar was immune to the miracle and in part the collapse that followed. The region's fortunes have been revived recently and now the former pariah state has emerged to hopefully benefit from this revival. In political and economic liberalization, it seeks to carve out a new niche in the economic dynamism of the region.

Concomitantly, this also involves certain political and social structures that might at first glance prove difficult. These include ethical investment and business, human rights and corporate social responsibility, in a society where these views are almost alien.

The analysis used constructivist theory broadly to explain that norms, ideas and institutions are crucial elements in the thematic relationship between Myanmar and the United Nations via the lens of the UN Global Compact (UNGC). This entails a business-societal relationship that claims a political mandate over the business sector. The UNGC operates as a networked agency that tries to frame business around basic normative principals such as human rights, labour standards and anti-corruption among others.

We conclude several things. The first is that the power of ideas vis-à-vis the UNGC is a positive and powerful force which can have an important impact in shaping business to work as a mechanism for back-door diplomacy and forge pathways to peace. However this must be tempered by the context and Myanmar is still an incredibly fragile state with a weak infrastructure that needs fixing.

Secondly it seems likely that hybrid-liberal peace investments will continue to be influenced more by Asia than by the West. Even with the launch of the UNGC. Myanmar will continue to rely heavily on its Asian neighbours especially China and Japan. Without a UNGC buy-in from Asian investors it is unlikely that the voluntary governance regime will have any 
meaningful impact. Myanmar is actively trying to gain access to the US market while diversify its investment portfolio by courting Western investors. Supporting the UNGC can help leverage Myanmar's reputation in a positive light if it can show it is serious about human development.

Finally the UNGC needs to deal with issues of vagueness as to its purpose and formulation and its serious lack of accountability and successful implantation in the areas it works. There is extensive confusion and understanding of what the UNGC signals amongst some of the signatories while CSR continues to be a weak concept in the country. Without a concerted effort to build a vibrant local UNGC network, CSR will never capture the imagination of local entrepreneurs and human rights will remain a low priority for business. All of these processes are still to a large extent in their infancy and the growing pains will likely get worse before they get better.

\section{Bibliography}

Adler, E. (1997) "Seizing the middle ground: Constructivism in world politics". In European Journal of International Relations. Vol. 3:3, pp. 319-63.

Amnesty. (2010). 'Myanmar - Amnesty International Report 2010'. Available from http://www.amnesty.org/es/node/20493> Accessed on 25 May 2013.

Asian Development Bank. (2012). 'Myanmar in Transition Opportunities and Challenges'. Available from <http://www.adb.org/sites/default/files/pub/2012/ myanmar-in-transition.pdf> Accessed on 22 May 2013.

Asian Human Rights Commission (2012). 'The State of Human Rights in Burma, 2012'. Available from <http://www.humanrights.asia/resources/hrreport/2012/ ahrc-spr-004-2012.pdf/view> Accessed on 25 May 2013.

Australia News Network. (2013). 'Call for 'ethical' investment in Burma'. Available from <http://www.abc.net.au/news/2013-03-14/an-burma-foreign-investment/ 4573290> Accessed on 25 May 2013.

Barkemeyer, R. (2009). Beyond compliance - below expectations? CSR in the context of international development. In Business Ethics: A European Review, Vol. 18: 3, pp. 273-289.

Bissinger, J. (2012). 'Foreign Investment in Myanmar: A Resource Boom but a Development Bust?' In Contemporary Southeast Asia, Vol. 34:1, pp. 23-52.

Bloomberg. (17 April 2013). 'Suu Kyi Says Laws, Infrastructure Stalling Investment in Myanmar'. Available from <http://www.bloomberg.com/news/2013-0417/suu-kyi-says-laws-infrastructure-stalling-investment-in-myanmar.html> Accessed on 25 May 2013.

Bloomberg. (19 August 2012). 'Myanmar Economy May See Annual 8\% Growth for a Decade, ADB Says.' Available from <http://www.bloomberg.com/news/201208-20/myanmar-economy-may-see-annual-8-growth-for-a-decade-adb-says. html> Accessed on 25 May 2013.

Blowfield, M \& Murray, A. (2008). Corporate responsibility: A critical interdiction. Toronto: Oxford.

Caramani, D. (2011). Comparative Politics 2nd Ed, Toronto: OUP.

Cetindamar, D., \& Husoy, K. (2007). 'Corporate social responsibility practices and environmental responsible behavior: The case of the United Nations Global Compact'. In Journal of Business Ethics, Vol.76:2, pp. 163-176. 
Vol. 1, No. $1 \quad$ Christie \& Hanlon: Sustaining Human Rights and Responsibility...

Checkel, J. T. (1998). The constructivist turn in International Relations theory. In World Politics Vol.50:2, pp. 324-48.

Chen, M, Murphy, A and K. Murphy. (2012). 'Myanmar's New Foreign Investment Legal Regime'. Available from <http://www.mondaq.com/unitedstates/ x/231 548/international+trade+investment/Myanmars+New+Foreign+Investment+Lega 1+Regime> Accessed on 25 May 2013.

Cook, A.D. B. (2012). 'Myanmar's China Policy: Agendas, Strategies and Challenges'. In China Report, Vol. 48: 3, pp. 269-281.

Copeland, D. (2006). The Constructivist Challenge to Structural Realism: A Review Essay. In Constructivism and International Relations - Alexander Wendt and his critics by S. Guzzini and A. Leander, New York: Routledge, pp. 1- 20.

Corporate Social Responsibility Initiative. (2013). 'The Initiative Defining Corporate Social Responsibility'. Available from <http://www.hks.harvard.edu/mrcbg/CSRI/init_define.html> Accessed 25 May 2013.

David, R and I. Holliday. (2012). 'International sanctions or international justice? Shaping political development in Myanmar'. In Australian Journal of International Affairs, Vol. 66: 2, pp. 121-38.

Davis, M. (2012). The Perils of Incoherence: ASEAN, Myanmar and the Avoidable Failures of Human Rights Socialization? Contemporary Southeast Asia, Volume 34, Number 1, April 2012, pp. 1-22.

De Lang, N. E. (2012). 'Myanmar National Human Rights Commission's Conformity with International Standards'. In Asia-Pacific Journal on Human Rights and the Law Vol. 1 pp. 1-41

Economist. (2011). 'A new Great Game?' Available from <http://www.economist. com/node/21541071> Accessed on 25 May 2013.

Fritsch, S. (2008). 'The UN Global Compact and the global governance of corporate social responsibility: Complex multilateralism for a more human globalization?' In Global Society, Vol. 22:1, pp. 1-26.

Foreign Policy. (2012). 'Failed State Index 2012'. Available from <http://www. foreignpolicy.com/failed_states_index_2012_interactive> Accessed on 22 May 2013.

Fosnot, C. T. (1996). Constructivism: Theory, perspectives, and practice, (Ed). New York: Teachers College Press.

Freedom House. 2012. 'Rights Groups Express Strong Concern about Weak Requirements for U.S. Investment in Burma'. Available from $<$ http://www. free domhouse.org/article/rights-groups-express-strong-concern-about-weak-require ments-us-investment-burma> Accessed on 24 May 2013.

Forbes. (3 April 2013). 'Why Western Oil Companies Love Myanmar's Moe Myint'. Available from < http://www.forbes.com/sites/forbesasia/2013/04/03/whywestern-oil-companies-love-myanmars-moe-myint/> Accessed 25 May 2013.

Guardian. (31 Jan 2012).' Before the gold rush: Burma braces for march of the multinationals' Available from <http://www.guardian.co.uk/world/2012/jan/31/ burma-gold-rush> Accessed on 25 May 2013.

Gilbert, D.U. and M. Behnam. (2012). 'Trust and the United Nations Global Compact: A Network Theory Perspective'. In Business \& Society, Vol. 52:1, pp. 135-169.

Hanlon, R. J. and Christie, K. (2012). 'Influencing the Burmese Spring: Keys to Success for Canada'. Available from < http://www.asiapacific.ca/canada-asiaagenda/influencing-burmese-spring-keys-success-canada> Accessed on 25 May 2013. 
Hanlon, R. J. (2011). 'Engineering corporate social responsibility: elite stakeholders, states and the resilience of neoliberalism'. In Contemporary Politics, Vol. 17:1, pp. 71-87.

Holliday. (2011a). Burma Redux: Global Justice and the Quest for Political Reform in Myanmar. New York: Columbia UP.

Holliday, I. (2011b). 'Extending a Hand in Myanmar' In Dissent, Vol: 58: 2, pp. 1418.

Howe, B.M and S. Jang. (2013). 'Human Security and Development: Divergent Approaches to Burma/Myanmar'. In Pacific Focus, Vol. 28, pp. 120-143.

Human Rights Watch. (2012). "Burma: US Backtracks on 'Responsible Investment' Pledge" Available from <http://www.hrw.org/news/2012/07/11/burma-us-back tracks-responsible-investment-pledge> Accessed on 23 May 2013.

Human Rights Watch (2010). 'World Report 2010: Burma'. Available from <http:// www.hrw.org/world-report-2010/burma> Accessed on 22 May 2013.

Kell, G. (2012). ' 12 Years Later: Reflections on the Growth of the UN Global Compact' In Business \& Society, Vol.52:1, pp. 31-52.

Kubo, K. (2012). 'Trade Policies and Trade Misreporting in Myanmar'. In ASEAN Economic Bulletin. Vol. 29: 2, pp. 146-59.

Kulczuga, A. (2013). 'A Taste of Freedom: Burma's Guarded Optimism.' In World Affairs, March/April, pp. 32-40.

Leisinger, K. M. (2008). 'Stretching the Limits of Corporate Social Responsibility'. In Peace through Commerce: Responsible Corporate Citizenship and the Ideals of the United Nations Global Compact by O. Williams (ed). Notre Dame: University of Notre Dame Press, pp. 199-238.

McGrew (2008). 'Globalization and Global Politics'. In The Globalization of World Politics: An Introduction to International Relations by J. Baylis, S. Smith, and P. Owens (eds.), Toronto: OUP, pp 14-31.

Mizzima News. (13 July 2012). 'Asean MPs urge caution in Burma investment'. Available from <http://www.mizzima.com/business/7515-asean-mps-urge-cau tion-in-burma-investment.html> Accessed on 22 May 2013.

Mizzima News (7 June 2012) 'Epidemic' of land grabbing in Burma: report'. Available from <http://www.mizzima.com/business/7277-epidemic-of-land-grab bing-in-burma-report.html> Accessed on 22 May 2013.

Myanmar Times. (6 May 2013). 'Investment law having desired effect'. Available from <http://mmtimes.com/index.php/business/6653-fdi-makes-progres.html> Accessed on 25 May 2013.

Pick, D and H.H. Thein. (2010). 'Development failure and the resource curse: the case of Myanmar'. In International Journal of Sociology and Social Policy. Vol. 30: 5/6, pp. 267-279.

Post, J.E. (2012). 'The United Nations Global Compact : A CSR Milestone.' In Business \& Society, 52:1, pp. 53-63.

Rasche, A, Waddock, S. and M. McIntosh. (2012). 'The United Nations Global Compact: Retrospect and Prospect'. In Business \& Society, 52: 1, pp. 6-30.

Rasche, A., \& Kell, G. (Eds) (2010). The United Nations Global Compact: Achievements, trends and challenges. Cambridge: Cambridge University Press.

Reuters. (12 March 2012). 'Myanmar copper mine told to compensate for land grabs' Available from <http://www.reuters.com/article/2013/03/12/us-myanmar-mineidUSBRE92B0AA20130312> Accessed on 25 May 2013.

Risse, T., Ropp, S. and Sikkink, K. (Eds) (1999). The Power of Human Rights: International Norms and Domestic Change. Cambridge: Cambridge University Press. 
Ruggie, J. G. (2003). The United Nations and globalization: Patterns and limits of institutional adaption. In Global Governance, Vol. 9:3, pp. 301-321.

Selth, A. (2012). Myanmar's Police Forces: Coercion, Continuity and Change. In Contemporary Southeast Asia Vol. 34:1 pp. 53-79

Sagafi-nejad, T. (2008). The UN and transnational corporations: From code of conduct to Global Compact. Bloomington: Indiana University Press.

Smurthwaite, M. (2008). 'The purpose of the corporation'. In Peace through Commerce: Responsible Corporate Citizenship and the Ideals of the United Nations Global Compact by O. Williams (ed). Notre Dame: University of Notre Dame Press, pp. 13-54.

Sovacool, B. (2012). 'Environmental Conservation Problems and Possible Solutions in Myanmar'. In Contemporary Southeast Asia, Vol. 34:2, pp. 217-48.

Steinberg, D.I. (2012). 'The Problem of Democracy in the Republic of the Union of Myanmar: Neither Nation-State Nor State-Nation? In Southeast Asian Affairs, Vol. 2012, pp. 220-237.

Stiglitz, J. (2002). Globalization and Its Discontents. New York: W.W. Norton.

Sun, Y. (2012). 'China and the Changing Myanmar'. In Journal of Current Southeast Asian Affairs, Vol. 31:4, pp. 51-77.

Transparency International. (2012). 'Corruption Perceptions Index 2012' Available from http://www.transparency.org/cpi2012/results\#myAnchor1 Accessed on 25 May 2013.

United Nations Environment Programme. (n.d.). 'United Nations Global Compact Environmental Principles Training Package'. Available from <www.unep.fr /shared/publications/other/.../en/UNGC_TRAIN_ALL.pdf> Accessed 25 May 2013.

United Nations Development Programme. (2012). 'MDG Country Progress Snapshot: Myanmar'. Available from <http://mdgs.un.org/unsd/mdg/Resources/Static/Pro ducts/Progress2012/Snapshots/MMR.pdf> Accessed on 25 May 2013.

United States Department of the Treasury. (2008). 'What you need to know about U.S. Sanctions Against Burma (Myanmar)' Available from <http://www.treasury.gov/ resource-center/sanctions/Documents/burma.pdf> Accessed on 25 May 2013.

Waddock, S. (2013). Context and Dynamics of the UN Global Compact: An Idea Whose Time has come. In Globally Responsible Leadership: Managing According to the UN Global Compact. By J.T. Lawrence and P.W. Beamish (eds). Los Angeles: Sage, pp. 51-67.

Waddock, S., Mirvis, P., and K. Ryu, (2008). 'United Nations Global Compact Leading Companies Retreat Summary Report'. Available from <http://www. gncc.org/sites/gern.cccdeutschland.org/files/BCCCC_UNGC\%20Leading\%20Co mpanies\%20Retreat_2008.pdf> Accessed 25 May 2013.

Wang, C, Wang, F, Wang, Q, Yang, D, Li. L and X. Zhang. (2013). 'Preparing for Myanmar's environment-friendly reform'. In Environmental Science and Policy, Vol. 25, pp. 229-33.

Wendt, A. (1999). Social Theory of International Politics, Cambridge: Cambridge University Press.

Wendt, A. (1992). Anarchy is what states make of it: the social construction of power politics. International Organization, Vol. 46:2, pp.391-425.

World Bank. (2013). 'Myanmar Overview.' Available from <http://www.worldbank. org/en/country/myanmar/overview> Accessed on 25 May 2013. 